\title{
Anxiety from receiving news about covid-19: The role of character strength
}

\author{
Junaidin $^{1}$, Nurulsani S. Abd. Latief ${ }^{2}$, Amalia S.J Kahar ${ }^{3}$ \\ ${ }^{1}$ Faculty of Psychology, Universitas Teknologi Sumbawa, Indonesia \\ ${ }^{2}$ Faculty of Social and Political Science, Universitas Muhammadiyah Maluku Utara, Indonesia \\ ${ }^{3}$ Faculty of Teacher Training and Education Science, Universitas Khairun Ternate, Indonesia \\ Corresponding author: iunaidin@uts.ac.id
}

ARTICLE INFO

\section{Article history}

Received August 12, 2020

Revised December 18, 2020

Accepted January 14, 2021

Keywords

anxiety;

covid-19;

character strength.

\begin{abstract}
The spread of covid-19 is happening in all countries, including Indonesia. The number of positive patients in Indonesia continues to increase. Whereas the news related to covid-19 informed by various media tend to cause psychological disorders, including anxiety. The strength of character is one of the individual capacity to prevent anxiety. Therefore, this study aimed to examine the effect of character strength on anxiety when receiving the covid-19 news. Four hundred sixty-one participants that have been chosen through snowball sampling, involved in this study. Data were collected with Character Strength Scale and Hamilton Anxiety Rating Scale. Simple regression analysis was used to analyze the data. The results show that character strength significantly predict anxiety when participant receive news about Covid-19. Consideration in developing character strength is needed to reduce anxiety during pandemic covid-19.
\end{abstract}

\section{Introduction}

In December 2019, the emergence of a pneumonia case was first reported in Wuhan, Hubei Province. From mid-December to the end of December, five patients were diagnosed with the virus, which was named by the World Health Organization (WHO), Severe Acute Respiratory Distress Syndrome Corona Virus 2 (SARS-Cov-2), and the name of the disease was coronavirus disease 2019 (Covid-19). Up to January 2020, this case increased rapidly, with 44 reported cases, and in less than a month, the disease had spread to various provinces and 65 countries that had contracted this virus, including in Indonesia (Susilo et al., 2020; Yuliana, 2020).

Based on the research of Paraskevis et al. (2020), bats have a very high incidence of coronaviruses. With this zoonotic principle, this virus is then transmitted from animals to humans. In general, Covid-19 is a respiratory infection that appears caused by coronavirus syndrome (SARS Cov-2), which is transmitted from human to human (Pan et al., 2020). Furthermore, Pan et al. (2020) categorized the most common clinical symptoms arising from Covid-19: fever, cough, dyspnea, headache, muscle aches, and fatigue. However, each individual varies in term of clinical symptoms experienced.

This virus then has a speedy period, has resulted in a total of 73.451 cases in 26 countries, with 1.875 deaths from February to March 2020 (Bernheim et al., 2020). Meanwhile, data was updated on December 2020 in 220 countries worldwide, with the number of confirmed cases reaching 63.360.234 people and cases of death increasing by 1.475.825 people. With the development of cases and the number of significant mortality 
rates increasing in various countries, the World Health Organization (WHO) officially declared on January 30, 2020, a global health emergency both physically and psychologically due to the outbreak. Covid-19 (Bernheim et al., 2020). In Indonesia up to December 2, 2020, there were 549.508 positive sufferers, 458.880 people recovered, and 17.199 people who died (KPCPEN, 2020).

Various types of news or information about the spread of Covid-19 through person to person, newspapers, online media and TV broadcasts are increasingly widespread and widespread in most countries. These data facts become information or news that will lead to the psychological response among individuals. A study in China shows patients, professionals, and the general public are under insurmountable psychological pressure and stress that cause various psychological problems such as anxiety, fear, depression, and insomnia Lin et al. (2020). While in Indonesia, based on the data from the Indonesian Psychiatric Specialists Association (PDSKJI), among 1552 respondents experiencing psychological changes such as stress, worry, anxiety, frustration, annoyance, anger, despair, panic, depression, mood changes, fear, or excessive anxiety (Aziz, 2020). Therefore, it is also crucial for individuals to pay on their psychological health, especially their anxiety (Agung, 2020).

Anxiety is defined as a particular psychological condition such as feelings of sadness, excessive fear, and even despair in responding to situations or circumstances (Myers, 2014; Weiten, 2013). Therefore, anxiety may be experienced by every individual in their everyday life. However, excessive anxiety may raise problem. Anxiety is also known as a state of feeling (mood) characterized by physical symptoms such as physical tension and worry about the future (Barlow, Durand, \& Stewart, 2015). Even though anxiety is a psychological condition, it may manifest into both physically and psychologically symptoms.

In psychology, the imbalance between psychological resources and individual strength to manage news or information about the spread of Covid-19 will impact mental health or psychological health, including the possibility to experience anxiety. Three psychological aspects of an individual associated with an imbalance between information and psychological power are psychological, physical, and social (Li, Duan, \& Guo, 2017).

According to Peterson \& Seligman (2004), character strength is the power of cognition that affects a person's will and behavior. Character strength includes positive traits related to obtaining and using the information in a better and wiser life service (Rashid \& Niemiec, 2014). Therefore, character strength is vital in this pandemic covid-19, especially to manage information. Character strength is also described as an essential personal quality that should be proposed to be productive and critical for optimal human development for life (Abasimi, Gai, \& Wang, 2017). Individuals with character strength will process the news well and be useful for themselves and the environment. With strong character strength, individuals usually produce authentic positive emotions needed to reduce anxiety that may raise during pandemic covid-19.

Character strength is one aspect of positive psychology that aims to help individuals grow and maintain a sense of personal wellbeing and increase individual self-values that contribute to wellbeing and happiness. Peterson \& Seligman (2004) provide a more conceptual and fundamental view in positive psychology about character strength as a form of practical application to help individuals identify their strengths to use, increase, and maintain wellbeing socially, spiritually, and psychologically. Gustems \& Calderon (2014) found that character strength is positively related to students' psychological wellbeing, such as love, humor, justice, honesty, curiosity, and self-regulation.

Furthermore, Peterson \& Seligman (2004) identified 24 aspects of character strength in positive psychology, namely creativity, curiosity, judgment, love of learning, perspective, bravery, perseverance, honesty, zest, love, kindness, social intelligence, teamwork, fairness, leadership, forgiveness, humanity, prudence, self-regulation, appreciation of beauty and excellence, gratitude, hope, humor, and spirituality. Then the 24 aspects of character strength 
are classified into six core aspects to define it as a positive personal quality that leads to growth and development as a human being individual, namely creativity, curiosity, perspective, love of learning, courage, and transcendence (Morente, Mora, Nadal, Belled, \& Berenguer, 2018).

This current study aimed to determine the effect of character strength on anxiety in receiving the news of Covid-19. This research is important to provide information for the government and social media in controlling the Covid-19 news. This study hypothesis that character strength predicts anxiety in receiving the news of the covid-19.

\section{Method}

\section{Research Design}

This research applied a quantitative approach with ex-post facto to determine the cause-effect relationship without manipulation or treatment (Sappaile, 2010). Data were collected through an online system as this study was conducted during lock-down and social distancing. Figure 1 describes the steps of this study.

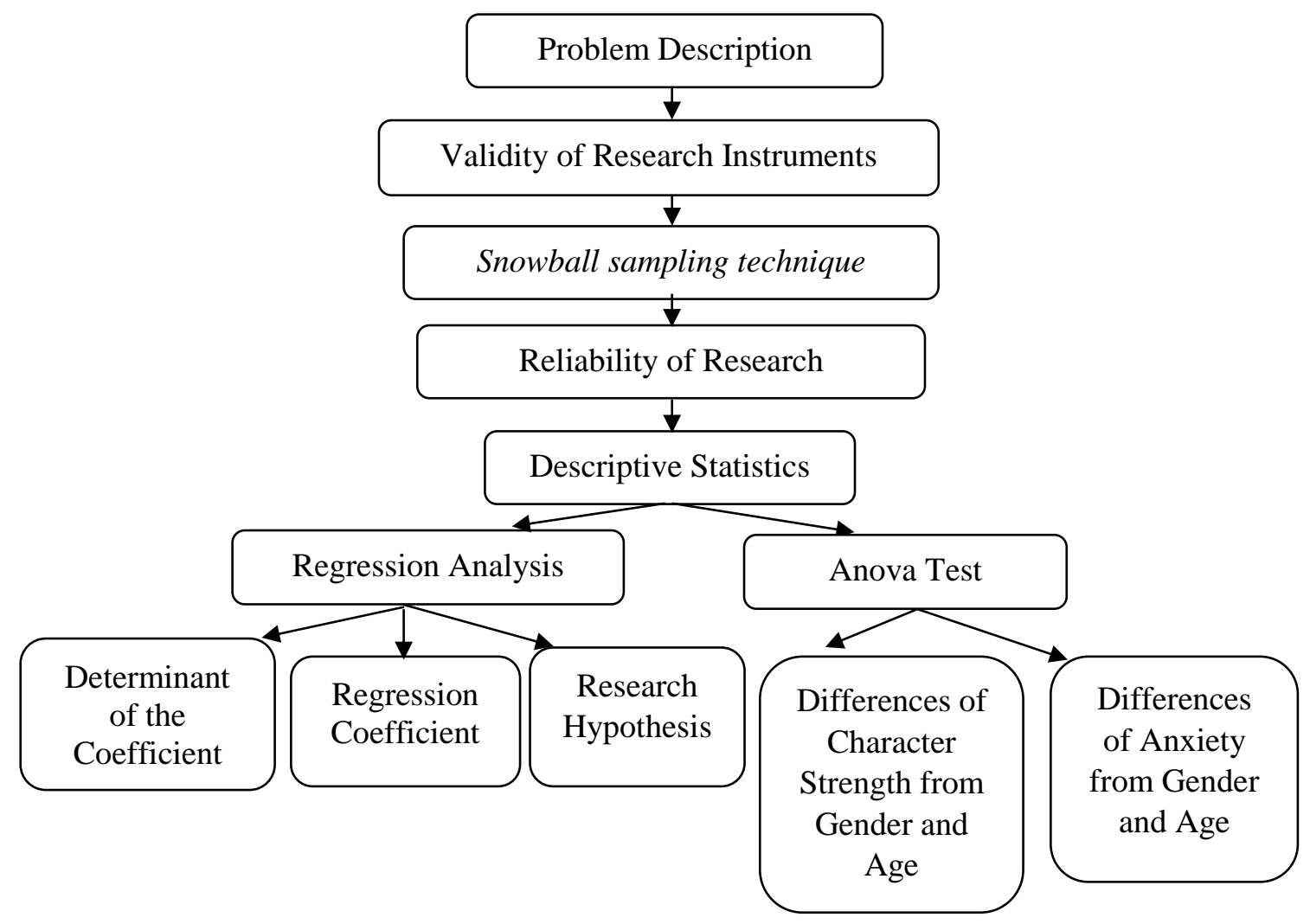

Figure 1. Research stages

\section{Participants}

Participants are Indonesian citizens who live in Indonesia, that have been chosen using the snowball sampling technique. The age of participants ranging from 20 to 50 years old. The number of participants was 461 (176 male and 285 female), as shown in Table 1 . The majority of participants are single (72\%). Whereas based on the age group, participants in 20 to 25 years old is the most, followed by age group 26 to 40 years old. 
Table 1

The Distribution of Study Participants

\begin{tabular}{cllcc}
\hline No & & Classification & Amount & Percent $(\%)$ \\
\hline 1 & Gender & Female & 285 & 62 \\
& & Male & 176 & 38 \\
2 & \multirow{2}{*}{ Marital Status } & Single & 329 & 72 \\
& & Married & 126 & 27 \\
& & Divorce & 6 & 1 \\
\multirow{2}{*}{3} & \multirow{2}{*}{ Age } & 20-25 years & 245 & 53 \\
& & 26-40 years & 189 & 41 \\
& & 41-50 years & 26 & 6 \\
\hline
\end{tabular}

\section{Instruments}

Two instruments were used to collect the data in this study. The Character Strength Scale was developed by Ruch et al. (2014). It refers to the theory of Peterson \& Seligman (2004), which consists of six aspects of character strength, namely creativity, curiosity, perspective, love of learning, courage, and transcendence. The Character Strength Scale consists of 24 items with an item discrimination index ranged from .397 to .631 with reliability $\alpha=.942$. The questionnaire's validity was tested using external validity by making comparisons to find similarities with facts that occurred in the field. The items were adjusted to empirical events or facts in the population related to the context of a respondent's criteria, the method, and the time needed during the study.

Hamilton Anxiety Rating Scale (HARS), developed by Hamilton (1959), was used to measure anxiety. The HARS has been adapted in the Indonesian version by Ramdan (2019), which consists of two aspects, namely psychological symptoms (mental agitation and psychological pressure) and somatic symptoms (physical complaints related to anxiety). The HARS consist of 14 items with an item discrimination index ranged from .491 to .670 , with reliability $\alpha=.899$.

\section{Data Analysis}

Data were analyzed with regression linear to find out whether character strength predicts anxiety. ANOVA test was then applied as additional analysis to determine the difference of character strength and anxiety based on gender and age.

\section{Results}

Table 2 describes the descriptive statistics for each variable, including mean, standard deviation, also maximum and minimum value obtained.

Table 2

Descriptive Statistics

\begin{tabular}{lcccc}
\hline \multicolumn{1}{c}{ Variable } & Mean & Sd. Deviation & Minimum & Maximum \\
\hline Character Strength & 95.49 & 13.086 & 24 & 120 \\
Anxiety & 11.44 & 8.655 & 0 & 52 \\
\hline
\end{tabular}

Table 3 shows the results of regression analysis, with the $F=13.232$ and $p=.000$. The result indicates character strength predicts anxiety in receiving the Covid-19 news. The more character strength, the lower anxiety, and vice versa. 
Table 3

Regression Analysis

\begin{tabular}{lcrccc}
\hline \multicolumn{1}{c}{ Model } & Sum of Squares & $d f$ & Mean Square & $F$ & Sig. \\
\hline Regression & 965.555 & 1 & 965.555 & 13.232 & .000 \\
Residual & 33494.172 & 459 & 72.972 & & \\
Total & 34459.727 & 460 & & & \\
\hline
\end{tabular}

The value of $R^{2}$ or the determinant coefficient obtained in the character strength variable is .028 , which indicates that the character strength contributes to anxiety amounted $2.8 \%$. Therefore, $97.2 \%$ of anxiety is influenced by other factors.

ANOVA test results show no difference in character strength in terms of gender $(F=.17$; $p=.692)$. Meanwhile, there is a difference in anxiety in age groups $(F=4.941 ; p=.008)$. It can be concluded that there is a very significant difference in character strength in terms of age group, where the age group of 26-40 have the highest character strength than those two other age groups.

On the contrary, the ANOVA test results indicate no difference in anxiety in age groups $(F=1.510 ; p=.222)$. Meanwhile, there is a difference in anxiety in terms of gender $(F=4.431$; $p=.035)$. Anxiety among females is higher than that of males.

\section{Discussion}

Character strength is an important object in the study of positive psychology. Based on this study's results, character strength predicts anxiety when individuals are receiving news about covid-19. According to Peterson \& Seligman (2004), individuals who have good character strength have 6 six basic aspects of 24 characters in positive psychology. Previous research shows that character strength is considered the key to optimizing human wellbeing and function and is vital to improve welfare and function among mentally and psychologically healthy individuals (Husna \& Saidiyah, 2014).

Regarding the covid-19 news, the character strength and anxiety are correlated. This is due to the proliferation of emerging information that makes people misperceive the news and results in psychological shocks for those who access it. The news that appears tends to be scary and makes high tension and fear, especially news related to the death rate due to Covid19 (Astrid, 2020). Therefore, in receiving the Covid-19 news, character strength has a very significant influence on anxiety. The character strength of Indonesian people becomes a strong capacity to overcome anxiety in receiving news about Covid-19.

This study's results align with Rashid \& Niemiec (2014) stated that character strength represents the dimensions of cognition and behavior. Character strength contributes to individual and social wellbeing (Subhashini, 2020). Moreover, Luisa \& Ruch (2017) argue that character strength predicts resilience and optimism, which are very important during a pandemic Covid-19.

The highest character strength is the age group of 26-40 years old. This result aligns with Martinez-Marti \& Ruch (2014) finding on the difference character strengths such as love, kindness, humor, and spirituality/religiosity based on age groups. The age group of $27-$ 36 years old has significantly higher character strength scores than that of the 47-57 years old. Meanwhile, the difference in anxiety based on gender was also found in this research. Previous research found that women consistently have a higher prevalence rate of anxiety disorders than men (McLean, Asnaani, Litz, \& Hofmann, 2011). Moreover, the anxiety experienced by women is also more disturbing than men. 
The limitation of this study is that this study was conducted during the regulation of social distances. Hence data collection could not be conducted directly face to face. An online survey has been done to collect the data.

\section{Conclusion}

Character strength is significantly correlated with anxiety from receiving the Covid-19 news. Increasing character strength will reduce anxiety. On the contrary, decreasing character strength will increase anxiety. The contribution of character strength to anxiety amounted to $2.8 \%$, while other factors influenced the remaining $97.2 \%$. Therefore, to reduce anxiety during pandemic covid-19, character strength needs to be considered and developed.

\section{References}

Abasimi, E., Gai, X., \& Wang, G. (2017). Character strengths and life satisfaction on high school students. International Journal of Applied Psychology, 7(2), 36-43. https://doi.org/10.5923/j.ijap.20170702.02

Agung, I. M. (2020). Memahami pendemi covid-19 dalam perspektif psikologi sosial. (Understanding covid-19 pandemic in social psychology perspective). Psikobuletin: Buletin Ilmiah Psikologi, 1(2), 68-84. https://doi.org/10.24014/pib.v1i2.9616

Astrid, A. F. (2020). Jurnalisme positif ala Portal Republika pada isu covid-19 (Positive journalism in the style of Republika Portal on covid-19 issue). Jurnal Mercusuar, 1(1), $150-161$.

Aziz, A. (2020). Survey: 64,3\% dari 1552 orang cemas dan depresi karena covid-19 (Survey: $64.3 \%$ of 1552 people are anxiety and depression because of covid-19). Retrieved from https://tirto.id/survei-643-dari-1522-orang-cemas-depresi-karenacovid-19-fgPG

Barlow, D. H., Durand, V., \& Stewart, S. H. (2015). Abnormal psychology: An integrative approach. Nelson Education.

Bernheim, A., Mei, Z., Huang, M., Yang, Y., Fayad, Z. A., Zhang, N., \& Chung, M. (2020). Ches ct findings in coronavirus disease-19 (COVID-19): Relationship to duration of infection. Radiology, 295(3), 685-691. https://doi.org/10.1148/radio1.2020200463

Gustems, J., \& Calderon, C. (2014). Character strengths and psychological wellbeing among students of teacher education. Journal of Educational Psychology, 3(3), 265-286. https://dx.doi.org/10.4471/ijep.2014.14

Hamilton, M. (1959). The assessment of anxiety states by rating. The British Journal of Medical Psychology, 32(1), 50-55. https://doi.org/10.1111/j.20448341.1959.tb00467.x

Husna, S., \& Saidiyah, S. (2014). Kekuatan karakter dan kesejahteraan subjektif penduduk dewasa muda asli Yogyakarta (Character strength and subjective wellbeing among the original young adult population of Yogyakarta). Psikologika, 19(1), 3-11. https://doi.org/10.20885/psikologika.vo119.iss1.art1

KPCPEN. (2020). Data sebaran situasi virus corona Indonesia. (Distribution of the corona virus in Indonesia). Retrieved from http://www.Covid19.go.id

Li, T., Duan, W., \& Guo, P. (2017). Character strengths, social anxiety, and physiological stress reactivity. PeerJ, 5, e3396. https://doi.org/10.7717/peerj.3396

Lin, W., Yang, Y., Liu, Z., Zhao, Y., Zhang, Q., Zhang, L., \& Xiang, Y. (2020). Progression of mental health services during the COVID-19 outbreak in Cina. International Journal of Biological Cinces, 10(16), 1732-1738. 
Luisa, M. M., \& Ruch, W. (2017). Character strengths predict resilience over and above positive affect, self-efficacy, optimism, social support, self-esteem, and life satisfaction. The Journal of Positive Psychology, 12(2), 110-119. https://doi.org/10.1080/17439760.2016.1163403

Martinez-Marti, M. L., \& Ruch, W. (2014). Character strengths and wellbeing across the life span: data from a representative sample of German-speaking adults living in $\begin{array}{lllll}\text { Switzrland. Frontiers in Psychology, } & \text { 5, } & 1253 .\end{array}$ https://doi.org/10.3389/fpsyg.2014.01253

McLean, C. P., Asnaani, A., Litz, B. T., \& Hofmann, S. G. (2011). Gender differences in anxiety disorders: prevalence, course of illness, comorbidity and burden of illness. Journal of Psychiatric Research, 45(8), 1027-1035. https://doi.org/10.1016/j.jpsychires.2011.03.006

Morente, A. R., Mora, C. A., Nadal, C. T., Belled, A. B., \& Berenguer, N. S. (2018). An examination of relationship between emotional intelligence, positive affect, and character strengths and virtues. Anales de Pscologia, 34(1), 63-67. https://doi.org/10.6018/analesps.34.1.262891

Myers, D. G. (2014). Psychology special update for DSM-V (10th edition). Whorth Publisher.

Pan, A., Liu, L., Wang, C., Guo, H., Hao, X., Wang, Q., .. \& Wu, T. (2020). Association of public health interventions with the epidemology of the COVID-19 outbreak in Wuhan, Cina. Journal American Medical Association, 323(19), 1915-1923. https://doi.org/10.1001/jama.2020.6130

Paraskevis, D., Kostaki, E. G., Magiorkinis, G., Panayiotakopoulos, G., Sourvinos, G., \& Tsiodras, S. (2020). Full-genome evolutionary analysis of the novel corona virus (2019$\mathrm{nCoV}$ ) rejects the hypothesis of emergence as a result of a recent recombination event. Infection, Genetics and Evolution: Journal of Molecular Epidemiology and Evolutionary Genetics in Infectious Diseases, 79, 104212.

Peterson, C., \& Seligman, M. (2004). Character strenghts and virtues: A hand book and classification. American Psychological Association.

Ramdan, I. M. (2019). Reliability and validity test of the Indonesian version of the Hamilton Anxiety Rating Scale (ham-a) to measure work-related stress in nursing. Jurnal Ners, 14(1), 33-40. https://doi.org/10.20473/jn.v14i1.10673

Rashid, T., \& Niemiec, R. M. (2014). Character strenghts. A. Michalos (Ed). In Encyclopedia of quality of life and well-being research. Springer.

Ruch, W., Martinez-Marti, M. L., Proyer, R. T., \& Harzer, C. (2014). The character strengths rating form (CSRF): Development and initial assessment of a 24-item rating scale to assess character strengths. Personality and Individual Differences, 68(53-58). https://doi.org/10.5167/uzh-95983

Sappaile, B. I. (2010). Konsep penelitian ex-post facto (Ex-post facto research concept). Jurnal Pendidikan Matematika, 1(2), 1-9.

Subhashini, P. (2020). Character strenghts for post covid-19 growt. Journal Community Guidance \& Research, 37(1), 3-18.

Susilo, A., Rumende, C. M., Pitoyo, C. W., Santoso, W. D., Yulianti, M., Herikurniawan, \& Yunihastuti, E. (2020). Coronavirus disease 2019: Tinjauan literature terkini (Coronavirus disease 2019: Recent literature review). Jurnal Penyakit Dalam Indonesia, 7(1), 45-67. https://dx.doi.org/10.7454/jpdi.v7i1.415

Weiten, W. (2013). Psychology themes and variations (9th edition). Wadsworth.

Yuliana. (2020). Corona virus diseases (Covid-19); Sebuah tinjauan literature (Corona virus diseases (Covid-19): A literature review). Wellness and Healthy Magazine, 2(1), 187- 
192. https://doi.org/10.30604/well.95212020 